\title{
Desain dan Modifikasi Sistem Elektrolit Air Laut dengan Penambahan Bahan Alumina
}

\author{
M. Iqbal Yuliansyah ${ }^{(\mathrm{a}) *}$, Gurum Ahmad Pauzi ${ }^{(\mathrm{b})}$, Warsito $^{(\mathrm{c})}$ \\ Jurusan Fisika FMIPA, Universitas Lampung, Bandar Lampung, Indonesia, 35145 \\ Email: (a*) Muhammadiqbal.ibr38@gmail.com, ${ }^{(b)}$ gurum4in@yahoo.com, ${ }^{(c)}$ Warsito@fmipa.unila.ac.id
}

Diterima (18 September 2019), Direvisi (15 Januari 2020)

\begin{abstract}
It has been done realization electrolyte system based on seawater has been revised with the addition of alumina variations. This research was aimed to study the influence of alumina on the characteristics of the voltage and current produced. Variation of alumina used is 2 grams and 4 grams. The testing process was carried out using 40 electrolyte cells with a pair of $\mathrm{Cu}$-Zn electrodes in each cell. The testing time is carried out for 24 hours for each variation of alumina. The result are relatively the same, namely a voltage of 26,9 volt and a current of 2,5 $\mathrm{mA}$ for each variation of alumina.
\end{abstract}

Key words: Alumina, Cu-Zn electrode, electrolyte sea water

\begin{abstract}
Abstrak: Telah direalisasikan sistem elektrolit berbasis air laut dengan penambahan variasi Alumina. Penelitian ini bertujuan untuk mengetahui alumina terhadap karakteristik tegangan dan arus yang dihasilkan. Variasi alumina yang digunakan yaitu sebanyak 2 gram dan 4 gram. Proses pengujian dilakukan menggunakan 40 buah sel elektrolit dengan sepasang Zn dalam tiap selnya. Waktu pengujian dilakukan selama 48 jam dengan pergantian elektrolit sebanyak 2 kali untuk tiap variasi alumina. Hasil pengujian relatif sama yaitu menghasilkan tegangan sebesar 26,9 volt elektroda $\mathrm{Cu}$-dan arus sebesar 2,5 mA untuk tiap variasi alumina, sehingga diketahui bahwa alumina yang di berikan tidak memberikan perubahan yang signifikan terhadap hasil tegangan, dan arus.
\end{abstract}

Kata Kunci: Alumina, Elektroda Cu-Zn, Elektrolit Air Laut.

\section{PENDAHULUAN}

Indonesia sebagai negara kepulauan yang sebagian besar dari luas negaranya merupakan lautan. Lautan Indonesia merupakan sumber mata pencarian bagi masyarakat yang hidup di pinggir pantai, namun lautan yang begitu luas sebagai sumber daya alam saat ini belum dimanfaatkan secara maksimal dalam sektor energi.

Energi pada laut terdiri dari dua tipe yaitu energi yang memanfaatkan arus laut untuk menghasilkan energi listrik pada pulau-pulau kecil [1] dan energi yang memanfaatkan kandungan air laut, perbedaan suhu, dan salinitas dari air laut untuk menghasilkan energi. Apabila salah satu dari dua tipe energi air laut tersebut dapat dimaksimalkan penggunaannya maka diperkirakan akan dapat memenuhi kebutuhan listrik yang terus meningkat.

Salinitas merupakan jumlah gram-garam yang terlarut dalam $1 \mathrm{~kg}$ air laut [2] Salinitas air laut terdiri dari $96,5 \%$ air murni dan $3,5 \%$ zat terlarut. Zat terlarut yang terdapat pada air laut diantaranya adalah klorida, natrium, sulfat, magnesium, kalsium, potasium, bikarbonat, bromida, asam borak, strontium dan fluorida. Dari sekian banyak zat terlarut kandungan klorida dan natrium merupakan zat terlarut yang paling besar konsentrasinya [3]

Saat ini banyak penelitian untuk memperoleh energi baru terbarukan dengan menggunakan air laut sebagai objek utama. 
Berdasarkan penelitian yang telah dilakukan dihasilkan penerangan untuk sampan dengan memanfaatkan air laut sebagai elektrolit yang disebut dengan Sea cell, yang mampu menghasilkan tegangan \pm 15 volt per $1 \mathrm{~kg}$ air laut [4].

Penelitian yang lain yang dilakukan oleh Imamah menunjukkan bahwa variasi elektroda dan jarak antar elektroda menghasilkan nilai arus dan tegangan yang berbeda, hasil penelitian semakin dekat jarak elektroda maka nilai tegangan dan arus yang dihasilkan semakin besar [5].

Berdasarkan penelitian yang dilakukan tentang thermoelectric, hasil penelitian menunjukkan bahwa elektrolit air laut yang digunakan menghasilkan arus keluaran hingga 4,2 mA tetapi arus yang dihasilkan tidak stabil, sedangkan elektrolit $\mathrm{Al}_{2} \mathrm{O}_{3}$ nanofluid menghasilkan arus keluar yang stabil dengan besar arus yaitu 1,08 mA. Jika keduanya digabungkan maka akan menghasilkan elektrolit yang arus keluarannya besar dan stabil [6].

Penelitian lain dilakukan juga oleh Wang dan Wang tentang perbandingan elektrolit alumina nanofluida dengan elektrolit alam (air laut, air mineral, dan air keran) perbandingannya menunjukkan bahwa tegangan yang dihasilkan dari pengukuran elektrolit alumina nanofluida selama 10 jam dengan interval waktu pengambilan selama 1 jam hasilnya menunjukkan bahwa elektrolit alumina Nanofluida memiliki tegangan yang stabil dibandingkan elektrolit alam [7].

Diperlukan penelitian tentang pengaruh penambahan alumina dengan konsentrasi tertentu terhadap air laut. Penelitian ini dapat menghasilkan baterai air laut yang cocok untuk aplikasi daya rendah jangka pendek [8].

\section{METODE PENELITIAN}

Penelitian ini dilakukan dengan mendesain sebuah alat untuk menghasilkan energi yang dapat digunakan untuk penerangan dengan memanfaatkan alam sebagai objek utama. Penelitian ini memanfaatkan air laut sebagai bahan elektrolit dan menggunakan pasangan elektroda $\mathrm{Cu}-\mathrm{Zn}$, alat yang dibuat didesain untuk dapat digunakan berulang kali.

Prosedur penelitian terdiri beberapa tahapan yaitu desain dan pembuatan alat untuk tempat elektrolit kemudian pengujian alat berupa tegangan, arus, dan daya untuk mengetahui karakteristik yang dihasilkan dari setiap elektrolit yang di uji yaitu air laut murni, air laut yang di filter, dan air laut yang diberi tambahan variasi alumina. Desain bertingkat digunakan untuk tempat elektrolit. Desain elektrolit dapat dilihat pada Gambar 1.

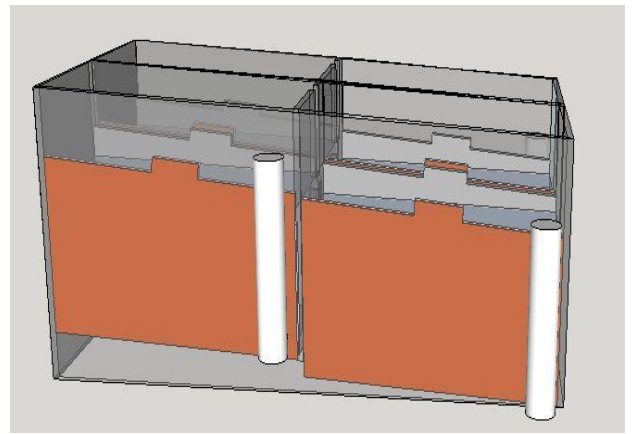

(a)

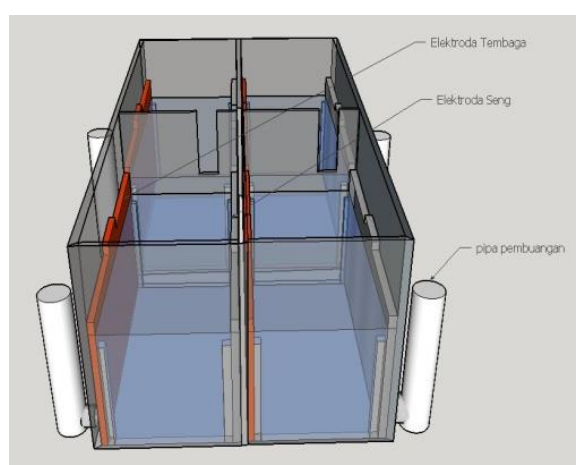

(b) 


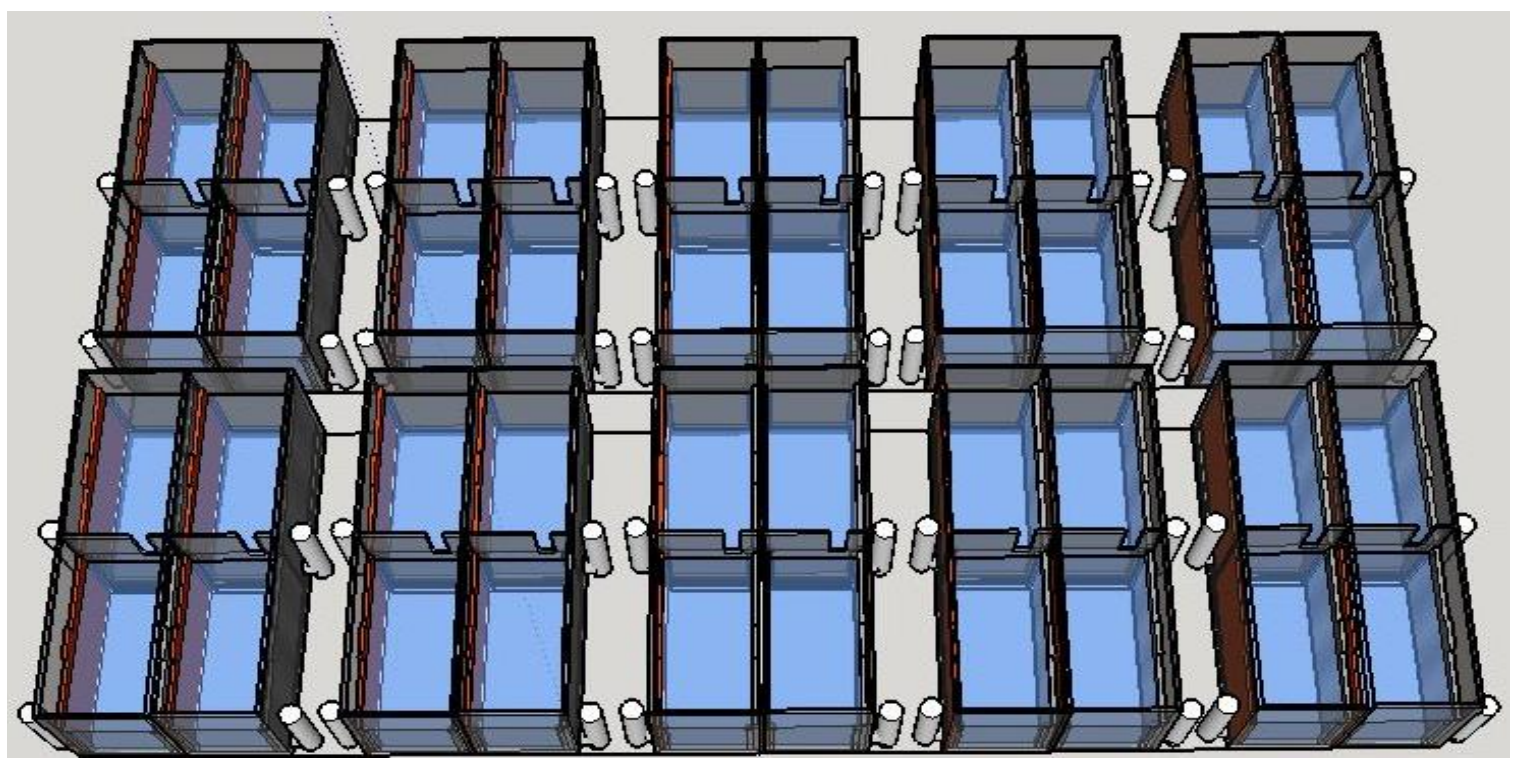

(c)

Gambar 1. (a) Desain sel elektrolit tampak samping; (b) Desain sel elektrolit tampak depan yang terdiri dari 4 buah sel; (c) Desain sel elektrolit tampak atas yang terdiri dari 40 buah sel.

\section{HASIL PENELITIAN}

Realisasi sistem elektrolit air laut dibuat menggunakan bahan akrilik ketebalan $2 \mathrm{~mm}$, dengan sel elektrolit sebanyak 40 buah yang 1 buah sel berkapasitas $100 \mathrm{ml}$ air laut. Energi yang dihasilkan sebanding dengan banyaknya sel elektrolit [9] dan memiliki sepasang elektroda $\mathrm{Cu}-\mathrm{Zn}$ pada setiap sel. Elektroda $\mathrm{Cu}$ dan $\mathrm{Zn}$ memiliki panjang tinggi $7 \mathrm{~cm}$ dan lebar $5 \mathrm{~cm}$, dengan jarak antar elektroda sejauh $2 \mathrm{~cm} \mathrm{[5].}$

$\mathrm{Zn}$ adalah bahan yang mudah melepaskan elektron sehingga berfungsi sebagai Anode, dan $\mathrm{Cu}$ berfungsi sebagai Katode karena merupakan bahan yang sulit melepaskan electron [10][11]. Penelitian sebelumnya degan jumlah sel dan pasangan elektroda yang sama menghasilkan nilai tegangan sebesar14,29 V dan arus sebesar 3,21 mA dengan beban berupa led berdaya 1,2 watt [12]. Zn merupakan bahan yang mudah di dapat dan terjangkau sehingga memungkinkan untuk diaplikasikan pada penggunaan sekali pakai selain itu merupakan elektroda yang menghasilkan output lebih besar dibandingkan Al dan Galvalume [13]. Sistem elektrolit air laut ini mampu menghidupkan 1 buah lampu LED 12 volt dengan daya 3 watt selama kurang dari 1 jam.

Alat dibuat dengan sistem pengisian yang menggunakan tempat penampung elektrolit yang dihubungkan dengan selang dan kran yang berfungsi untuk mengontrol aliran elektrolit yang mengalir menuju sel. Realisasi alat di tunjukan pada Gambar 2.

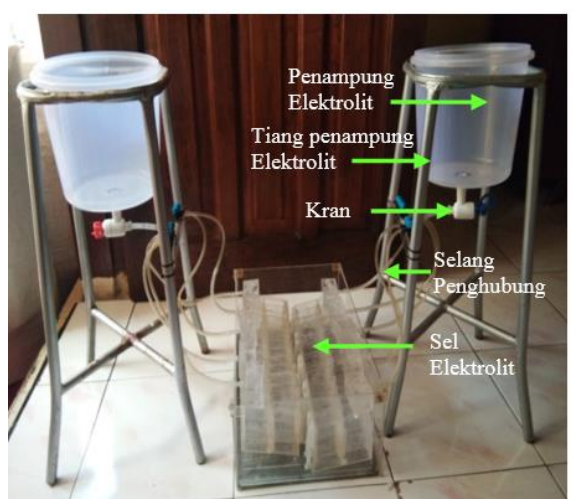

(a) 


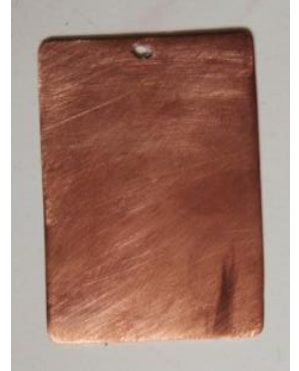

(b)

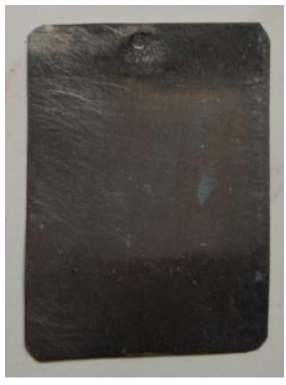

(c)
Gambar 2. (a) Sistem Elektrolit air laut; (b) Elektroda $\mathrm{Cu}$; (c) Elektroda $\mathrm{Zn}$

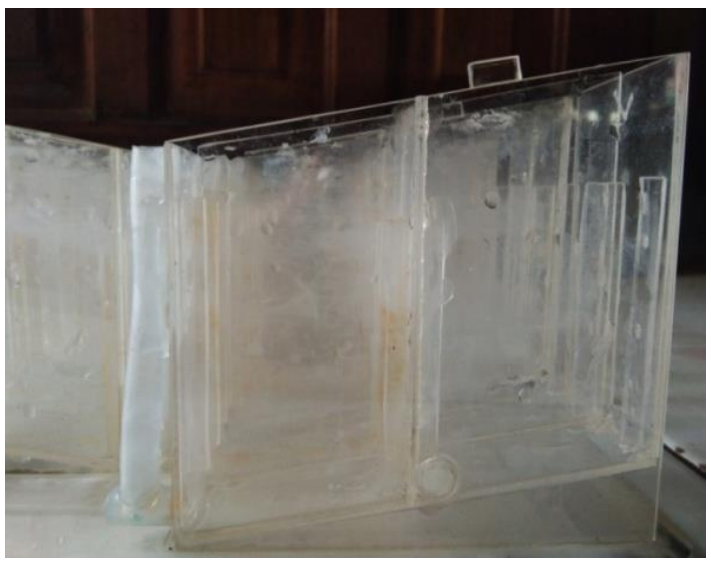

Gambar 3. Sel Elektrolit Bertingkat

Sel elektrolit yang dibuat di desain secara bertingkat bertujuan agar mempermudah proses pengisian sel elektrolit, sehingga apabila sel yang lebih tinggi telah terisi penuh oleh elektrolit (air laut) yang mengalir dari tempat penampungan yang lebih tinggi maka elektrolit (air laut) akan mengalir ke sel yang berada di bawahnya.

Pergantian elektrolit dilakukan setelah penggunaan selama 24 jam hal ini dikarenakan penurunan daya yang terjadi lantaran elektrolit yang digunakan mengalami penurunan ionisasi [14]. Sehingga daya yang mampu dihasilkan oleh sel elektrolit berkurang setia waktu. Bentuk dari sel elektrolit yag dibuat bertingkat di tunjukkan oleh Gambar 3.

Berdasarkan data yang diperoleh didapati bahwa karakteristik arus dari elektrolit yang diuji yaitu air laut murni

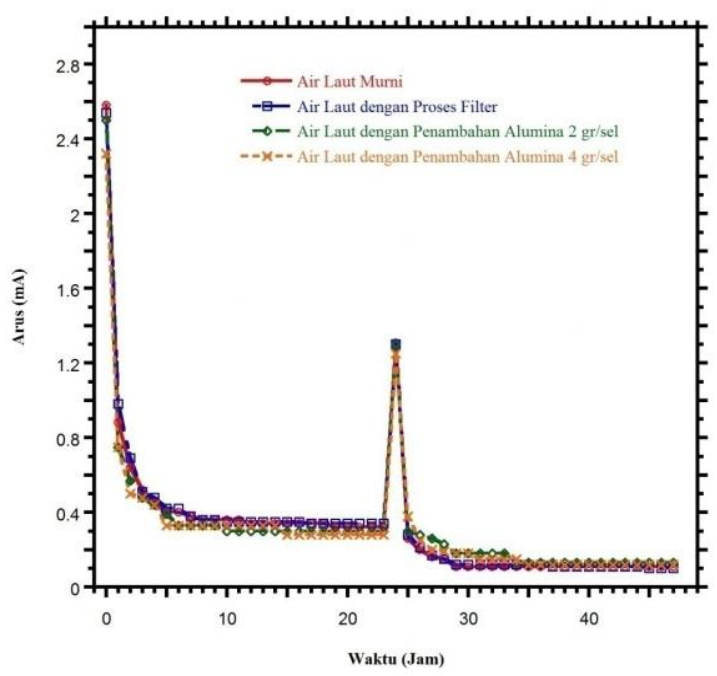

Gambar 4. Grafik Karakteristik Arus

dan air laut yang di filter menunjukkan hal yang sama yaitu arus yang terukur pada pengukuran awal sebesar $2.58 \mathrm{~mA}$ yang kemudian menunjukkan nilai arus konstan sebesar 0,34 mA setelah penggunaan selama 9 jam. Pergantian elektrolit setelah penggunaan selama 24 jam menyebabkan kenaikan pada nilai arus sebesar 1,31 mA yang kemudian pada jam berikutnya mengalami penurunan kembali.

Karakteristik arus dari elektrolit air laut yang diberikan penambahan variasi alumina 2 gr dan $4 \mathrm{gr}$ menunjukkan hal yang sama yaitu arus yang terukur pada pengukuran awal sebesar $2.50 \mathrm{~mA}$ arus mulai konstan pada nilai $0.33 \mathrm{~mA}$ setelah penggunaan selama 7 jam. Dan pergantian elektrolit setelah penggunaan selama 24 jam menyebabkan kenaikan pada nilai arus sebesar 1,28 mA. Grafik karakteristik arus ditunjukkan oleh Gambar 4.

Karakteristik Tegangan dengan beban LED 12 volt dari elektrolit air laut murni dan air laut yang di filter menunjukkan hal yang sama yaitu arus yang terukur pada pengukuran awal sebesar 17,64 volt yang kemudian menunjukkan nilai tegangan konstan sebesar 11,56 volt setelah pengunaan 


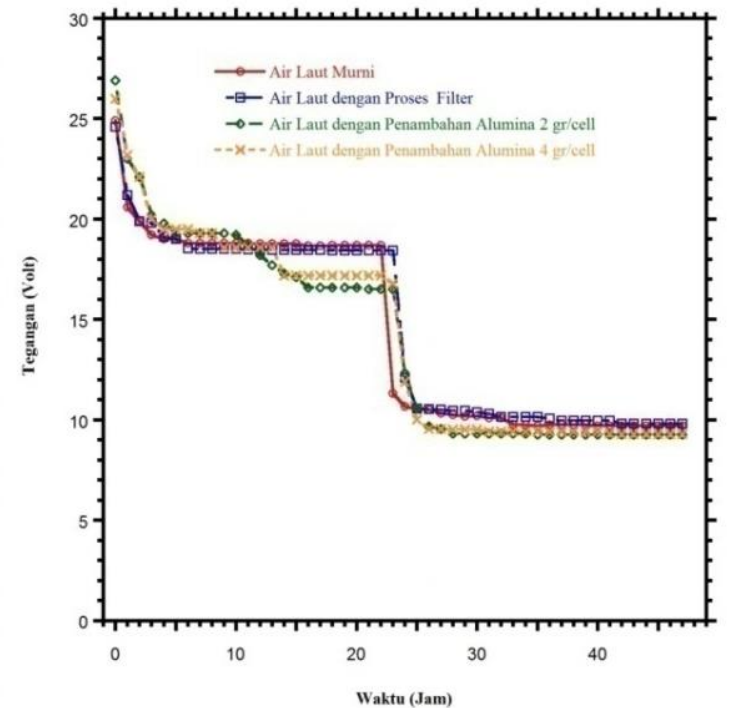

Gambar 5. Grafik Karakteristik tegangan berbeban

selama 24 jam menyebabkan penurunan pada nilai tegangan sebesar 4,98 volt tetapi hal ini disertai dengan kenaikan pada intensitas cahaya yang dihasilkan.

Karakteristik tegangan dari elektrolit air laut yang diberikan penambahan variasi alumina $2 \mathrm{gr}$ dan $4 \mathrm{~g}$ menunjukkan hal yang sama yaitu tegangan yang terukur pada pengukuran awal sebesar 15,50 volt tegangan mulai konstan pada nilai 7,7 volt setelah penggunaan selama 5 jam. Dan pergantian elektrolit setelah penggunaan selama 24 jam menyebabkan penurunan pada nilai tegangan sebesar 4,98 volt tetapi hal ini disertai dengan kenaikan pada intensitas cahaya yang dihasilkan.

Penurunan tegangan ini terjadi karena elektrolit mengalami keadaan jenuh di mana senyawa yang terkandung dalam sel elektrolit sudah mengalami reaksi elektrokimia sehingga dengan jangka waktu tertentu arus listrik yang dihasilkan akan habis dan menunjukkan nilai arus/tegangan yang konstan. Grafik karakteristik tegangan ditunjukkan oleh Gambar 5.

Karakteristik daya dari elektrolit yang diuji yaitu air laut murni dan air laut yang di filter menunjukkan hal yang sama yaitu daya yang terukur pada pengukuran awal sebesar 45,5 $\mathrm{mW}$ yang kemudian menunjukkan nilai daya konstan sebesar 4,19 $\mathrm{mW}$ setelah penggunaan selama 9 jam. Pergantian elektrolit setelah penggunaan selama 24 jam menyebabkan kenaikan pada nilai daya sebesar $6,52 \mathrm{~mW}$ yang kemudian pada jam berikutnya mengalami penurunan kembali.

Karakteristik daya dari elektrolit air laut yang diberikan penambahan variasi alumina 2 gr dan $4 \mathrm{gr}$ menunjukkan hal yang sama yaitu arus yang terukur pada pengukuran awal sebesar $38,75 \mathrm{~mW}$, daya mulai konstan pada nilai $2,54 \mathrm{~mW}$ setelah penggunaan selama 7 jam. Dan pergantian elektrolit setelah penggunaan selama 24 jam menyebabkan kenaikan pada nilai daya sebesar $6,37 \mathrm{~mW}$. Grafik karakteristik daya ditunjukkan oleh Gambar 6.

Penurunan yang signifikan terus terjadi pada semua jenis elektrolit yang diuji hal ini karena penggunaan seng sebagai anode menyebabkan kelebihan ion $\mathrm{Zn}^{2+}$, yang mengakibatkan ion bebas ini berpasangan pada ion negatif pada larutan elektrolit yang jumlahnya lebih sedikit membentuk lapisan garam pada Anode [15].

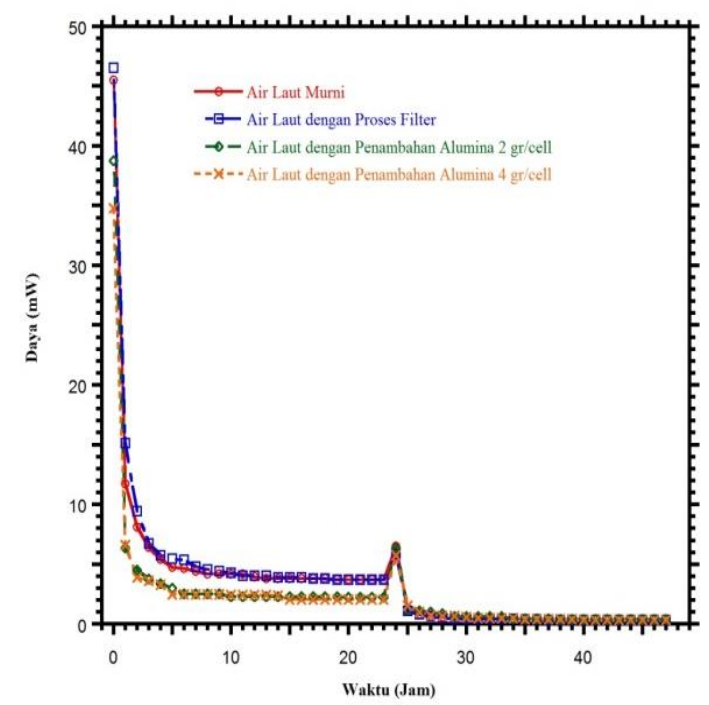

Gambar 6. Grafik Karakteristik Daya 


\section{KESIMPULAN}

Berdasarkan pengujian yang telah dilakukan diketahui bahwa penambahan alumina serbuk pada elektrolit air laut tidak memberikan efek yang signifikan pada perubahan arus dan daya yang dihasilkan serta volume elektrolit tidak berpengaruh terhadap nilai tegangan tetapi berpengaruh terhadap lama hidup lampu LED yang digunakan.

\section{DAFTAR PUSTAKA}

[1] Y. Suryansyah, "Potential Energy Of Ocean Current For Electric Power Generator In Small Island (Study: Mantang Island- Bintan, Abang Island-Batam and Sugi Island-Karimun Riau Islands Province)," J. Kelaut. Nas., vol. 8, no. 1, 2013.

[2] F. J. M. Millero and S. Miller, Chemical Oceanography. Florida: CRC Press, Inc., 1992.

[3] J. W. Nybakken, "Biologi Luat Suatu Pendekatan Ekologis." Gramedia Pustaka, Jakarta, 1992.

[4] S. Fariya and S. Rejeki, "Seacell ( Sea Water Electrochemical Cell ) Pemanfaatan Elektrolit Air Laut Menjadi Cadangan Sumber Energi Listrik Terbarukan Sebagai Penerangan Pada Sampan," J. Sain dan Teknol., vol. 10, no. 1, pp. 4458, 2015.

[5] A. noor Imamah, "Antar Elektroda Terhadap Kelistrikan Yang Antar Elektroda Terhadap Kelistrikan Yang," Skripsi, 2013.

[6] J. C. Wang and W. C. Chiang, "Researches on thermo-electric properties of seawater and $\mathrm{Al} 2 \mathrm{O} 3$ nanofluids," Appl. Mech. Mater., vol. 394, pp. 14-19, 2013.

[7] R. T. Wang and J. C. Wang, "Alumina Nanofluids As Electrolytes Comparisons to
Various Neutral Aqueous Solutions Inside Battery," $J$. Mech., vol. 32, no. 3, pp. 369-379, 2016.

[8] W. S. D. Wilcock and P. C. Kauffman, "Development of a seawater battery for deep-water applications," J. Power Sources, vol. 66, no. 1-2, pp. 71-75, 1997.

[9] F. Arizal, M. Hasbi, and A. Kadir, "Pengaruh Kadar Garam terhadap Daya yang Dihasilkan Pembangkit Listrik Tenaga Air Garam sebagai Energi Alternatif Terbarukan," ENTHalPY J. Ilm. Mhs. Tek. Mesin, vol. 2, no. 1, pp. 1-5, 2017.

[10] W. D. Jauharah, "Analisis Kelistrikan yang Dihasilkan Limbah Buah dan Sayuran sebagai Energi Alternatif Bio-Baterai," Skripsi, 2013.

[11] G. A. Pauzi, E. Hudaya, A. Suprianto, Warsito, and A. Surtono, "Analisis Uji Karakteristik Elektrik Air Laut Sebagai Sumber Energi Listrik Terbarukan," Pros. Semin. Nas. Sains Mat. Inform. dan Apl. IV, vol. 4, pp. 1-8, 2016.

[12] J. Aristian, "Desain Dan Aplikasi Sistem Elektrolit Air Laut Sebagai Sumber Energi Alternatif Berkelanjutan (Sustainable Energy)," Skripsi, 2016.

[13] A. Susanto, M. S. Baskoro, S. H. Wisudo, M. Riyanto, and F. Purwangka, "Seawater battery with $\mathrm{Al}-\mathrm{Cu}, \mathrm{Zn}-\mathrm{Cu}, \mathrm{Gal}-\mathrm{Cu}$ electrodes for fishing lamp," Int. J. Renew. Energy Res., vol. 7, no. 4, pp. 1857-1868, 2017.

[14] G. A. Pauzi, R. K. Arwaditha, and A. Supriyanto, "Desain dan Realisasi Akumulator Elektrolit Air Laut dengan Penambahan Sodium Bicarbonate (NaHCO3) sebagai Sumber Energi Alternatif," J. Teor. dan Apl. Fis., vol. 8, no. 2, 
pp. 135-142, 2018.

[15] A. M. Udi and F. Kurniawan, "Simulasi Prototipe on Field Battery Melalui Pemanfaatan
Perbedaan Salinitas Dengan Beberapa Pasangan Elektroda," $J$. Sains dan Seni POMITS, vol. 1, no. 1, pp. 1-5, 2013. 
M. Iqbal Yuliansyah : Desain dan Modifikasi Sistem Elektrolit Air Laut Dengan Penambahan Bahan Alumina 